\title{
Regionalism, Federalism and Nationalism in the German Empire
}

ivegfried Weichlein

Regions and regionalism had a great impact on developments in nineteenthrentury Germany. The century began with a genuine territorial revolution in liebruary 1803 that ended the independent history of hundreds of regional slates and brought their number down to 34 . After several hundred years of relative continuity this was a clear break with the past. Bringing the number of German states down further to 27 and taking away much of their indepenIence with the unification of Germany in 1871 was then a comparatively small step. What had begun in the late eighteenth century - the dissociiltion of territory and political power - reached a certain climax in 1803. liarly-modern small state particularism, nevertheless, had a lasting impact on regionalism as well as nationalism. Deprived of their political power the old German states still fostered a sense of the 'federative nation' (föderative Nation).${ }^{1}$ Regional identity was therefore still a veritable cultural and political lorce which could support a call for federalism.

Regions could be coextensive with a state, but also exist below the states and between them. A good example is the Palatinate. Since the late righteenth century it belonged politically and administratively to Bavaria. Culturally and to a certain extent politically, however, representatives of the Palatinate kept their distance from the capital Munich. In this the Palatinate did not stand alone. Many sub-state regionalisms explicitly or implicitly referred to their political borders before the French Revolution. Regions like Lower Franconia around Würzburg or Westfalen around Münster had been former bishoprics that had lost their political independence under Napoleon. Throughout the nineteenth century they were respectively part of Bavaria and Prussia, but nevertheless kept a sense of distinctiveness in relation to other regions and particularly to their new administrative centres in Munich and Berlin. The new Bavarian state and particularly Baden inherited hundreds of ecclesiastical and imperial territories in 1803. The citizens of these dissolved entities experienced their political transfer to new authorities as a loss. The end of the ecclesiastical territories, for instance, resulted 
in the disappearance of social welfare and elementary education in many parts of the new Bavaria, where these functions had been administered by monasteries.

This was quite different in the second wave of territorial reorganisation in 1866 when the Prussian annexation of Hesse-Kassel, Nassau, the city of Frankfurt and the kingdom of Hannover was, despite some resistance, welcomed and experienced as a net gain. The dynasties in these states had not based their autocratic regimes on the loyalty of their people and were not held in high esteem, and the new administration tried to maintain as many local institutions and legal provisions as it could. As a result, the elections of 1867 in these new Prussian territories were won by the National-Liberals, the party of Bismarck. The annexations of 1866 did not, therefore, result in a fierce oppositional movement, and only rarely did a sub-state regionalism develop afterwards in these areas.

How can the regionalisms in the German 'Länder' (e.g. Bavaria) and on a sub-state level (e.g. Franconia) theoretically be understood? They do not relate to each other as politicisation and de-politicisation or as political and cultural regionalism. On the one hand, sub-state regionalisms were cultural as well as political. They preserved a memory of historical statehood, in the Palatinate ended by the defeat of its 'winter-king' Frederic V in 1620 at the beginning of the Thirty Years' War, in Lower Franconia finishing in the baroque era and so on. They all had their historical memory of political and cultural importance. These memories generated a sense of uniqueness and independence even after their statehood had disappeared. During the Weimar Republic the strength of these sub-state regionalisms could still be seen in the election results, when former Catholic territories like Friesoythe and Cloppenburg - then a part of predominantly Protestant Prussia - voted overwhelmingly Catholic.

On the other side, regionalisms coinciding with a state like Bavária or Saxony were not simply nationalisms writ small. Their political utopia lay with the monarchical order and not with the people's sovereignty or the nation-state. If Bavarian patriots referred to the Bavarian nation, they did so in a completely different manner than the Prussian National-Liberals. Not the political ideals of a democratic and constitutional nation-state but rather the monarchy or even the dynasty - as in Bavaria the 700-year-old Wittelsbach dynasty or in Saxony the 800-year-old Wettiner dynasty - provided continuity and identity for these state regionalisms. The participatory character of liberal nationalism was a challenge for regionalisms of all sorts.

Regionalisms in the German Confederation and later in the German Reich had therefore specific relationships with the states, which set them apart from regionalisms in other European nation-states. Two characteristics made the German case terminology specific and differentiated it from developments elsewhere:
I 1. German history at the end of the ninetereenth century knew two forms of regionalism: first that of the rising miniddle-sized states, like Bavaria Württemberg and Saxony. Their regionalidism was old (except for Baden, which did not exist as such before 1809,9) and had always had a state, but their societies had been totally reconsistituted in the Napoleonic era. This kind of regionalism was partly deferensive against the encroaching nation-state, partly offensive, since it foought for the loyalty of its citizens. The other form was constituted $k$ by sub-state regionalisms like those in Franconia or the Palatinate, terriritories that had been incorporated into the new middle-sized states bbut also into Prussia. Sub-state regionalism therefore refers in the Germann case to these type of sub-state regionalisms, not to sub-(nation-)state regigionalisms on a central German level. German regionalisms were thus f part of a multi-level political system.

2 ?. This was facilitated by the German type e of cooperative federalism that developed after the unsuccessful revolutionn of 1848. It reaffirmed the role of the state monarchies and did not replolace them by a single national identity. The cooperative federalism stipoulated that the federal legislation of the Reich was executed in practicee by the administrations of the states. Their administrative function was k kept in place. The regionalisms of the states had therefore no incentivive to being particularist, the sub-state regionalisms were nationalist rrather than secessionist. If the Palatinate went against Bavaria, it was wwith a pro-German nationalist intention.

'I 'The references to history, historical statehoood and monarchies were typical i Ior state-regionalism up until the 1870 s. That t did not mean that the glory of

$t$ the region for them lay only in the past and that regionalism could be asso-

c ciated with traditionalism. Quite to the contitrary: Abigail Green has shown

i in her book Fatherlands that the monarchs inin Hannover and Württemberg

f lostered a sense of monarchical loyalty throough embracing institutions of

r. modernity: for example, railroads or public fesestivities even before 1871 . That $\mathrm{s}$ set it apart from the other dynasties that Prusissia put an end to in 1866 . The f princes of Nassau and particularly of Hesse-e-Kassel, as well as the leading e clites of the Free City of Frankfurt had steacadfastly rejected economic and $f$ political reforms prior to the annexation. Thiheir subjects did not nurture a f positive memory of their rulers, and they didd not hold any affection for the $i$ independence of these states. ${ }^{2}$ The distinction drawn between cultural and f political regionalisms in Germany can therefoiore only be a gradual one. Politi. ical regionalism generally aimed at building uup a cultural base while cultural $r$ regionalism had in many cases a memory of $\mathrm{f}$ political independence.

What makes a region a region? It is nots simply a certain number of s square miles or a specific space. It is a socio-s-spatial phenomenon in which $t$ Ierritorially linked identities were connecteted to other factors, of which 
the political is the most obvious. ${ }^{3}$ Governuments administer spatially based regimes and try to create loyalty to them. Economic links can also refer to a spatial object. The widening of trade networks went along with a broader worldview. Nation-building alwayss implied market-building. Economy, transport and mobility inform spatial experiences and practices, which result in new social networks. Mack Walker identified the 'movers and doers' in the Bavarian home town of Weissenburg as those most sympathetic to the national cause. ${ }^{4}$ Religion also defined in- and out-group orientations, which implied a spatial and regional dimension. This could be seen best in the years of the anti-Catholic Kulturkampf. In the 1870s, part of the resistance in the Rhineland against the Kulturkampf legislation resulted from the conflict between the Catholic Rhenish periphery and the political and Protestant centre in Berlin.

This spatial dimension cannot be measured in square miles. It was a process of identification that held a social group together and reproduced it. Regionalism is an identification that tries to integrate a given social group through an abstract idea of what the region is. The region is not a geographical entity but rather a socio-spatial conceptt that wins its legitimacy through the persuasive force of geography, that is, the presumption that it is natural and self-evident and does not aspire to follow an abstract ideal. It is a form of abstract integration, just as the nattion is a form of abstract integration. ${ }^{5}$ The resulting community is an 'imagined community', where similar mechanisms come into play as with the nattion and nationalism. ${ }^{6}$

Benedict Anderson has argued that naticonalism sprang out of an idea of empty time. Print capitalism and the great narratives of the nation filled this empty time. The same can be said about empty space. In France the revolutionaries abolished the historical regions and replaced them with 83 departments, which were constructed on a rationalist basis and were only remotely associated with the regions; before 1789. The French Revolution thus created an empty space, which it filled with the new spatial construction of the departments.?

In 1871 with the founding of the Germnan Empire regionalism did not come to an end and was not dissolved in the nation-state. Through economic, administrative and cultural reformis regional actors in the German Bundesstaaten kept up with the wave of reforms and legislative change on national level. School reforms and new schoolbooks tried to imbue a sense of regional and of national pride into the children. Administrative reforms allowed for new businesses and mobility. (Cities like Frankfurt, Cologne or Munich epitomised modernisation. ${ }^{8}$ This form of regionalism presented modernisation in its purest and most sirmple form: massive progress in hygiene and sewage systems, more energy through electrification, disposal of waste, urban planning and new schools; and universities. That was generally the agenda of the small states and the cities. They were modernising themselves, which effectively meant a (re-)imvention of regionalism. Regions were able to adapt to the national and modernising environment. They were not simple remnants of tradition or leftovers from pre-modern times. ${ }^{9}$

Regionalism as well as nationalism and localism were thoroughly redelined during the German Empire, broadly speaking between 1867 and 1914 . Whereas small state regionalism and German nationalism had been divergent until the 1870s, several political mechanisms, cultural experiences and narratives resulted in convergence of regionalism and nationalism, beginning with the elites and then around 1890 for the broad masses. Here we can find an important caesura. The different modes of inclusion require a discussion of the different uses of history, politics and culture. In the following remarks, three overlapping dimensions of this shift from exclusion to inclusion in Germany will be sketched out.

\section{Regionalism, federalism and political integration}

Gerhard Lehmbruch has discerned at least four ways to cope with conflicts between the local and the national in the nation-state. First, party competition can nationalise the existing conflicts" and thereby transform regional conflicts into national ones. Solutions to similar problems faced by different regions would thereby be sought not where they began in the regions, but in the parliament and other national institutions. Second, an authoritarian monarchy or executive could try to use its power to subdue discord and thereby resolve conflicts. Third, systems characterised by a proportional government and parity in decision-making could solve conflicts and secure at the same time national unity. Finally federalism was the ultimate mechanism for conflict resolution. ${ }^{10}$ The latter was particularly the case in Germany.

Until 1848 federalism was generally seen as the way to organise democracy in a territorial state with political subunits. It was an emancipatory way to construct a German republic (Föderativrepublik) and thereby incorporate the existing monarchies. Federalist authors looked to the US constitution of 1787 and the 'Federalist Papers' in their attempt to construct a democratic nation-state based on a territorially divided area. These sources provided a strategy for left-wing democratic nationalists to transform territorial monarchies into a democratic state, where the rights of the individual states would be secured and the executive branch would be democratically legitimised. The impact of the Federalist Papers was particularly strong in Germany, but was also influential in Italy and Switzerland. ${ }^{11}$ Generally speaking, federalism was a driving force behind the national democratic movement.

This changed in 1848. The revolution of that year put an end to this more left-wing driven federalism in central Europe, although it survived in southern Europe and in Switzerland. In central Europe federalism was fully reinvented. The counter-revolutionary affirmation of monarchical sovereignty in $1848 / 1849$ made it clear that any future German nation-state would not 
be a republic, nor would it reform or transform the existing monarchies. It became clear that the federal scheme for the future nation-state had to include and secure the existing states and monarchies. The Göttingen law professor Georg Waitz and other moderate liberals now made the German states and their monarchies the cornerstones of a future German state ('Bundesstaat'). Waitz' theory of a divided sovereignty between the member states and the federative state worked with the underlying assumption that federalism was no longer a transformative, but rather an affirmative political strategy. It was no longer to be found on the political left, but on the political right.

This had lasting consequences. As a result the democratic and socialist traditions in Germany became unitary and opposed to federalism, as they have remained more or less until today. Their opposition to federalism dates back to the socialist perception of the German nation-state as established in 1871. For them it was a 'Fürstenstaat' and not a 'Volksstaat' as they had wanted. For socialists federalism became aligned with reactionary and anti-democratic politics. In opposition to the tradition of the Federalist Papers, a democratic state required for them a unitary conception of popular sovereignty to counter the anti-democratic politics of the nobility, which had its stronghold in the states. ${ }^{12}$

There was indeed ample evidence in the constitution of 1871 and in the attitude of Bismarck and his peers for an anti-democratic use of federalism, although on the surface this was not the case. ${ }^{13}$ The federal system of 1871 came with a dual chamber system. The national parliament was based on popular sovereignty, with 382 members of parliament, representing all 41 million Germans within its borders. In this it followed the electoral system introduced for the Reichstag of the German Northern Confederation in 1867 in which for the first time in German history all men over 25 could vote on an equal basis. The democratic principle included in universal suffrage was thus implemented in Germany much earlier than in Britain or Italy. A national party system soon developed afterwards with four parties, representing conservatism, Catholicism, liberalism and socialism, which became typical for most nation-states. The fierce conflicts of the 1870 s drove Catholics and socialists from all areas into organising their own national parties. The national parliament thus united people on the level of the nation-state.

This did not mean that the democratically elected Reichstag had its way. The upper house or Bundesrat, in which the 25 German states were, with the exception of Prussia, more or less represented according to the size of their population, had undue influence. The integration of the smaller states had been made easier through the constitutional provision that Prussia, with two-thirds of the German population, had only 17 of the 58 seats in the upper house. To pass legislation Prussia therefore needed the votes of at least two other, mostly southern German kingdoms. In addition Bavaria and
Württemberg were given exemptions from certain specific national legislalion. ${ }^{14}$ The Bundesrat was much more than a second chamber. The Reich was governed constitutionally through the Prussian crown, which acted as the head of the Bundesrat. Consequently the national parliament could not Mdress the government directly. The government was hidden behind the I' (leral structure. To attack the government meant effectively to criticise the Ibundesrat itself. Criticism of Chancellor Bismarck amounted automatically 11) criticism of 25 monarchs and city governments. And that was exactly low it was meant to work. The Bundeskanzler - de facto the head of the "i)vernment - was constitutionally nothing more than the secretary to the hicad of the Bundesrat. Federalism thus made ministerial responsibility to lise elected national parliament non-existent. Besides the chancellorship, the most important office in the German Empire was the Prussian foreign minister, who negotiated compromises with other states directly. Between 1867 ind 1890 both positions where held by one and the same person: Otto von lismarck.

Here 1890 was a turning point. The national dimension was strengthened lhrough being democratised. After his forced resignation in 1890 Bismarck lecame a mythological figure. Being sneered at by liberals, Catholics and socialists when he was chancellor between 1871 and 1890, he made a stunning career as 'Reichsgründer' and 'the Iron Chancellor' after his departure. l'art of this retrospective celebration was a way to criticise his successor, Wilhelm II, but more importantly he could function as a symbol of national integration beyond the dynasties, since Bismarck was not a member of a ruling family. Monuments and associations, student fraternities and yearly lestivities were devoted to Bismarck. His rise to mythological status after 1890 appealed to his various and different roles. Bismarck was perceived as fully Prussian and conservative as well as fully national and German. In terms of social anthropology he functioned as a 'trickster'. In the 1850 s he had been a staunch conservative opposing the liberals wherever he could, while in the 1860 s he had fought the constitutional conflict as prime minister for the crown against a liberal majority in the lower house. On the other hand he was invested with national characteristics: 'Reichsgründer' and almost the personification of the Reich for 20 years. Commemorating Bismarck bridged the gap between regionalism and nationalism in a conservative way. Through the memory of Bismarck the German nation-state at all its levels could be brought into one narrative that stood for the stability of that complex of opposites by bringing together two systems of conflict resolution: nationalism and federalism. ${ }^{15}$

Transforming regionalism into federalism was particularly attractive to conservative elites. This became clear early on when Bavarian patriots otherwise vehemently opposed to Prussia, Protestantism, liberalism and generally the North - had to decide whether Bavaria would join the German Reich or whether it would stay outside. Earlier elections had resulted in 
a majority of Catholic patriots in the Bavarian diet, mostly opposed to national unification under Prussian auspices. In the final debate in Munich on 21 January 1871, however, many patriots joined forces with the liber. als and voted for Bavarian entry into the Reich. They argued that staying out of the Reich would mean disintegration, since parts of Bavaria - the Palatinate and parts of Franconia - were sympathetic to the new national solution. Ironically it was their patriotism that made them vote for and not against Bavaria's entry. ${ }^{16}$ We can see the same arguments being used in relation to the position of Eastern European states after the end of the Cold War. The only way to keep political and territorial integrity under a regime of globalised markets and unstable democratic institutions was entering the EU. Seen from this viewpoint, surrendering sovereignty to the EU amounts to 'the rescue of the nation-state'. The entry of all of Bavaria or all of Württemberg into the German Empire similarly amounted to the rescue of its territorial integrity and its statehood. ${ }^{17}$

As a result of this form of conflict resolution the relations between the Reich and the German states (Bundesstaaten) were excellent. They were the political capital of the government. The disadvantages lay with those, who wanted to strengthen the national parliament or even democratic government. As a result of the loss of influence at the national level, liberals turned towards local government where they often obtained, for instance in Berlin, Frankfurt am Main, Cologne or Munich, a dominant role in city government. ${ }^{18}$ The biggest disadvantage in terms of the disintegrative impact lay in the alienation of the democratic left. Whereas federalism was able to include the regions, the states and their monarchies, it alienated at the same time the German Social Democratic Party (SPD: Sozialdemokratische Partei Deutschlands) and its allies. That came to be felt sharply after 1890 . The federal institutions were used to coordinate the anti-socialist laws ('Sozialistengesetze') effectively. At local level bureaucrats coordinated their anti-socialist zeal effectively over state borders. Federalism here provided the institutional backing for the coordinated fight against socialism. ${ }^{19}$

Whereas federalism clearly was able to bridge the divide between the regional and the national level in the 1870 s and 1880s, it was instrumental in sharpening the social and political divide between the governmental parties and the left. After 1890 much of its regional integrative impact was achieved through antisocialism.

\section{Regionalism and culturalism}

A second form of regional inclusion in the national narrative was culturalism or the cultural interpretation of regional identity. In the German Confederation between 1815 and 1866, regionalism had a clear political dimension. Thirty-five German states gave political weight and decision-making powe to their often newly created territories, which were in many cases assemblies i1 smaller units that had possessed political sovereignty before 1803 . The Witte bureaucracies and monarchies of, for example, Bavaria, Württemberg ilıl Baden were fairly successful in creating forms of state loyalty through "hooling and the public representation of the monarchies. Schools in liavaria, after 1848 under Maximilian II, brought together various regional frroups in Bavarian society in a sense of loyalty: the Upper Bavarians, llic Lower Bavarians and the Franconians from Lower, Middle and Upper lifanconia, the Swabians and the Palatinate. ${ }^{20}$ This loyalty had a political Imı)act, since it strengthened the ruling bureaucratic-monarchical condominium. Political regionalism and state sovereignty were thereby culturally inclerpinned.

After the founding of the empire in 1871, this dynamic changed. i.ulturalism essentially no longer strengthened the individual states, but the liation-state. It worked towards a depoliticisation of regional identity. The inltural reinterpretation of Bavaria, for instance, focused on Bavarianness bxyond the political activities of a Bavarian state. The new schoolbooks, mublic festivities and memorial activities all showcased Bavarian identity Ihrough history. But the history they connected with Bavaria was now cultural not political. It encompassed costumes and architecture, landsape and mountains, the monasteries and agriculture and above all the monarchy. A widely distributed Saxon schoolbook had a section on the state as a subsection under 'Heimat'. ${ }^{21}$ Saxony was included into the Reich llirough a combination of the 'narrower fatherland' (engeres Vaterland) ind the 'wider fatherland' (weiteres Vaterland). Generally the attributes of lhe state became connected with the national level, whereas the region had cultural and emotional qualities. One of the most important connections between localism, regionalism and national identity was made Il rough the 'Christian elementary school' (christliche Volksschule). It couched adherence to a national society in Christian terms with the regions as pillars of that specific German morality and domesticity ('Innerlichkeit'). Christian morality was attributed to Germany. The German Protestant tradilion threw its moral weight behind cultural nation-building. The same held Irue for Christmas that was made into a holiday that conveyed a sense of Germanness. ${ }^{22}$

An essential part of culturalism was the historicisation of regional identity. In all parts of Germany historical associations (Geschichtsvereine) sprang up and cultivated historical memory. ${ }^{23}$ Socially the educated bourgeoisie had the upper hand in these associations. They gave national values a historical basis. Regional history, such as Bavarian or Saxon history, was narrated in a national context. That meant, for instance, emphasising the Bavarian effort against the Hungarian invasions in the tenth century or the Saxon efforts against presumably Slavic incursions since the eleventh century. Historicising regional identity first meant reifying the actors as Bavarians or Saxons and the new regions as the (only) Bavaria or Saxony, and so forth, 
as if something like that had existed before the nineteenth century. For the readers of historical narratives regional identity therefore seemed natural. It had a longue durée of at least a thousand years, given that the Middle Ages now rose to prominence in historical imagination. Second, the historical associations narrated national history from its margins. Regions and ethnicities at the edge of the Holy Roman (presumably German) Empire were the central actors in defending it. The periphery therefore stood at the centre of this national narrative. That gave a sense of pride and inclusion of the periphery. The population of the German borderlands was thus attributed agency in the founding of the German nation-state.

Benefiting from the depoliticisation of regional identity the terminology of one people consisting of many tribes (ein Volk und viele Stämme) provided a way to express unity and diversity at the same time. The people or ' $V o l k$ ' were the Germans, the tribes were the Saxons, the Bavarians, the Swabians, the Hessians and so on. The rhetoric of one people in many tribes expressed national unity among the different German regions. This concept found its iconographic expression in the German Reichstag, which was opened in 1894. Its entrance showed the emblems of 20 different German tribes which represented the 25 German states and cities which formed the nation-state. The entrance of the Reichstag was surrounded by the heraldic mottos of the German kingdoms, such as 'Suum cuique' for Prussia, 'Providentiae memor' for Saxony or 'In Treue fest' for Bavaria. Expressing one's adherence to Germany and one's integrity as a group through the Volk/Stamm rhetoric was so successful that even some German Jews described themselves as 'Germans of the Jewish Stamm'. ${ }^{24}$

Referring to the Germanic tribes implied a historical approach. The impact of historical thinking on regionalism in the German Empire can be best observed in the 1880s when the festivities for the anniversaries of the Bavarian and Saxon dynasties were used for the exhibition of historical loyalty to the German cause. ${ }^{25}$ In 1880 the Munich liberal bourgeoisie celebrated the seven-hundredth anniversary of the Wittelsbach dynasty. Neither the dynasty nor the government took part due to the mental illness of Ludwig II and because of the general depoliticised character of the festivities. The monarchy was used rhetorically to express national Bavarian sentiments in various ways. For the Catholic bishops religion stood at the centre of the monarchical order, which had lasted for so long. Their message was: only the Church could mediate between the people and the monarchy, as a culturally protective force that had enriched Bavaria for so long. Liberals looked at the 700 years quite differently. They placed Bavaria and its monarchy at the centre of German history from its early stages. Nobody represented this invented tradition better than Ludwig the Bavarian, Holy Roman Emperor from 1328 to $1347^{26}$

In 1889 the Saxon Wettiner dynasty celebrated its own anniversary; it had a hundred years more to commemorate. The eight-hundredth .mmiversary celebrations in Dresden portrayed Saxon regionalism as a force (1) modernisation already in the Middle Ages. Its procession of regional Inclustrialists dramatised the industrial progress of the nineteenth century III historical costumes. The resulting impression was that the present-day manufacturers and industrialists in Saxony fulfilled a historical mission to hring modernity to Germany. The organisers showcased the historical efforts III) merits of Saxony in the modernisation of transport and communicafion under the recurrent leitmotif of the anniversary: 'We Saxons were the lirst...

The impression the festivities left behind was that the Wettiner dukes and emperors in the eleventh century represented - like the Wittelsbach Iynasty in Munich - Germany much earlier than the Hohenzollern in Berlin did, an observation that was not lost on the audience at the Elbe, I raditionally opposed to the house of Hohenzollern at the Spree. The direcIors of the festivities in Munich and Dresden considered their regions as (ierman long before some 'homines novi', the Hohenzollern in Prussia, rose Io prominence. Historical loyalty to the German nation had become a way to affirm regional identity together with national loyalty against the (laims of a Prussian historiography that tended to highlight the Prussian service to the German nation. ${ }^{27}$ The impact of festivities like these was that regionalism implied nationalism, and vice versa. Around 1900, local trade lairs (Gewerbeaustellungen) presented their products in order to outdo their competitors not just in artisanal and technical matters but also in national reputation.

After 1900, nothing showed better the inclusionary logic of nationalism towards regionalism than the rhetoric and cultural practice of Heimat a word that is so particularly German, that it can hardly be translated. Celia Applegate and Alon Confino have shown the career of the cullural practice associated with the Heimat movement in the Palatinate and in Württemberg. ${ }^{28}$ It started in the 1850 s in the Palatinate and grew in the $1880 \mathrm{~s}$. Heimat associations, pamphlets and festivities began to express the particularities and the uniqueness of the regional environment in the national language. Being unique as a Pfälzer or Swabian did not contradict being German. Quite the contrary: the Palatinate, a part of Bavaria, stood out in its nationalism against the Catholic Bavarian patriots in Munich. If Munich did not want to be German, the Palatinate under the influence of the Heimat movement considered itself no longer as Bavarian. Similar to the concept of one people and many tribes the movement did not force its followers to choose between the nation and the region. 'Nationalism could embrace their smaller worlds; Germanness could encompass their diversity. ${ }^{29}$ Before 1914, Heimat associations sprang up everywhere, particularly in those regions where industry was weak and migration high. Its emphasis on the local and presumably pre-modern lifestyle also brought it in opposition to modernism. The Heimat movement bridged the gap between 
the regions and the nation, but sharpened the conflict between modernism and anti-modernism within the national movement. ${ }^{30}$

\section{The impact of transport and social communication on} regionalism

Regional and national affiliations were also influenced by increased mobility and communication. Railways and postal services made communication, transport and mobility much easier at all levels. Crossing borders became common in 'Mitteldeutschland' as well as in the Rhein-Main area with its many former states. The railways reaffirmed the role of the federal states since the governments not only built national networks, but since the late 1870 s also domestic and local lines (Nahverkehr). When the local transportation systems were in place in the 1880 s, it became much easier to search for a job in a nearby town and maintain a family in a nearby village. That became an alternative to migration and strengthened regional loyalty. Traffic and transport crossed borders between the old states, but also intensified traffic within the larger states like Bavaria, Saxony or Württemberg and of course Prussia.

The postal services were one of the very few decidedly unitary institutions in the empire. The constitution of 1871 created an imperial post office. Outside Bavaria the postal services were reorganised on a unitary basis with headquarters in Berlin. Heinrich von Stephan, one of the most important progressive liberal politicians and administrators of his time, attempted to make the Imperial Postal Services into a nation-building institution. ${ }^{31}$ Stephan was also a convinced liberal free trader. Regional barriers to mobility and communication were abhorrent to him. The nationally unified postal service was in his eyes a first step towards an internationalism that would bring mankind to a higher qualitative level of existence. Through intensified communication people would lose their prejudices and develop a cosmopolitan spirit. His political arguments resonated even in Britain, where The Times wrote: 'Nothing is impossible with the German Postmaster-General., ${ }^{32}$

Indeed the Imperial Postal Services developed a national infrastructure of communication. Modelled on the British penny post of 1840, the Northern Confederation and later the German Empire introduced a nationwide postal delivery service for one price. It became as cheap to communicate over a long distance as within one's own region. Up to then postage had been based on distance, according to an economic rationale. It had been much more expensive for Dresdeners to write a letter to Berlin than to Leipzig. After 1867 Prussia (and of course Berlin) was no longer a foreign country for Saxons. The administrative infrastructure, as well as the system of collection and distribution of letters and postcards, was standardised and nationalised. Stephan became famous for his postal architecture. New imperial post houses were constructed throughout Germany. In many regions they were the only
IIritilutions representing the nation-state. ${ }^{33}$ Together with the other reforms 111 's' seemed to bring about a tangible utopia, in which space was abolished IIIII 'veryone was close to everyone else. ${ }^{34}$

Isıl this did not materialise. Indeed many more Germans wrote letters IIII communicated over long distances, but that did not mean that the local imisial communication within a town, city or region lost importance - in lit i it was strengthened. The increased communication on the national level In's not provide proof for Karl W. Deutsch's concept of national assimilaIIs 1 and the disappearance of regional and linguistic diversity through social 1.mmmunication. Instead different levels of communicative networks and np: 'ncies established themselves. The new infrastructure enabled increased linil, regional as well as national communication; it did not dismantle liwal and regional communication. The nation-state became a communicaIIve level and fact of its own, just as locality and region already were and 1.mained. ${ }^{35}$ The impact that social communication indeed had was that Ilı'se levels no longer existed independently from each other. Localism and regionalism were important factors, but they no longer worked against nitionalism. As local transportation helped create more national transporta1 ion, so did local postal communication serve to create national networks of i m mmunication. All these levels were intertwined in forms of mutual benefit, inutual exchange, assistance and participation.

The consequence of social communication was not a unitary society, but 1) growing uniformity of political decision-making on the levels of the city Ille region and the nation-state. All levels were maintained, but intensified , wial communication was crucial in ending particularism and transforming II into nationally compatible regionalism. Parliamentarism was not just a Maracteristic of the Reich or before that of the federal states. The adminisllative reforms of the $1870 \mathrm{~s}$ implemented a kind of parliamentarism in the listricts and in the cities - even in the Prussian East, where the authoritarian rule of the nobility had to accept the constitutional principle of the division if powers between an elected body and the executive. Even local government in these near-feudal parts of Prussia obtained the two branches of a legislative and an executive body after 1873 .

Transport and communication impacted in various other ways on the development of regionalism and nationalism. The planning and construclion of new cross-regional railway networks resulted in the creation of new traffic areas ('Verkehrsräume') that no longer coincided with regional lorders. Such new regions were 'Westdeutschland', 'Süddeutschland' and 'Norddeutschland', all based on railway networks. They mirrored less the political structure than the multicentred economic development with its various sub-state centres of industrialisation. ${ }^{36}$ Social communication also made it much easier to coordinate action between different places, a prerequisite to federalism and its stronger need for interstate coordination. furthermore it allowed for a strengthening of the infrastructural capacity of 
regional governments that was crucial for the internal integration. Regional and local social communication provided some coherence to everyday 118 within regional societies. The networks of railways and postal services wer part of the 'infrastructural capacity', which was, according to Daniel Ziblatts crucial for the fact that Germany with strong middle-sized regional stated developed into a federal state, whereas at about the same time Italy witl as many states but with less infrastructural capacities rejected a federal system. ${ }^{37}$

Finally social communication through its propagandists was a liberal endeavour. Whereas liberalism was generally identified with a unitary con cept of the nation-state in order to resist what they perceived as regional autocracies, the general principle for integration underlying their ideas relied on the concepts of net and network building. The net was originally under. stood as the sum of the connections between one city and another. The early railways connected cities and rarely stopped in between. Twenty years after the founding of the German Empire, nets and networks meant something completely differently. The liberal economical concept had given way to a much more diverse and multi-centric net. The communicative networks around 1900 were long as well as short distance and even included local ones. It was much easier to travel to and from Berlin, but the increased local transportation system also allowed workers to commute daily from the countryside, where they lived, to the cities. Local and regional networks fed the national networks, since they connected travellers from small villages and towns through a national network of railways and - after 1890 more and more - the telegraph. The intertwining of regional and national communicative networks thus bound the mechanics of nationalism to that of regionalism.

\section{Timing and outlook}

Around 1890 a new generation had experienced more than 20 years of national and regional infrastructure building. The 1890 was a turning point for regionalism and nationalism in so far as regionalism no longer was the addressee of national politics, but rather mass politics and the rise of the SPD posed the new challenges. Regional and national elites in most cases worked together, particularly in fighting socialism. Mass politics was organised in national organisations. Ideologically they included regionalism, but their organisations were highly nationalised. This held true for nationalist organisations like the Pan-German League as well as for the leftist SPD. Generally regionalism came under pressure from the new dynamics introduced by mass politics and imperialism. The Navy League and the build-up of a navy was, for instance, particularly popular, and that automatically implied the national level as landlocked Bavaria or Saxony did not possess a navy.
II we look at the twentieth century, the most important challenge to n.pionalism came from the rise of the welfare state, which gave the national 1.1mumunity a new dimension. Whereas liberal constitutionalism, Prussian Ir mininance and the determination not to be disisolved into a German nation. 111 . created a working relationship between regions and the nation-state, IIr. social question and the welfare state required national institutions and I'it new pressures on federalism. Universal social rights were introduced in III. 1880 s to lure the workers away from the socialist party. These social Iy lits did not make regional distinctions. Whereas Germany had 25 fed"wil states, it had only a single welfare state. The early years of the German limpire had laid the base for this welfare state, when the poor laws no lingyer made the city of birth but the city of residence responsible for pilyments in case of sickness or disablement. Social rights went with the workers wherever they settled. They were designed to transcend regional liatriers.

Social rights and political regionalism were therefore more at odds with "ich other than nationalism ard regionalism were. 'Social reform estabIlshed a new administrative domain for the central state, it established the weed for a new bureaucratic apparatus, and it promised to open up new sources of revenue for the Reich.... Bismarck's social legislation had a strong inti-federalist momentum. ${ }^{38}$ The 31 administrative units of the regional Insurance offices did not correspond with state boundaries. The centralisition of the welfare state became even stronger in 1911, when a single miational insurance for white-collar employees ('Angestelltenversicherung') was introduced. In the same year more than 20,000 regional funds were reorfianised in approximately 10,000 national funds on similar lines to the white-collar insurance. The centralising impact of the welfare state was made "vident in 1927 when under unemployed insurance a single central agency with 13 regional sub-branches replaced 22 state and 869 municipal agenries. ${ }^{39} \mathrm{It}$ is therefore no coincidence that the post-war Weimar Republic was not only much more developed in social policy, it was also a much more unitary state than the German Empire.

\section{Notes}

1. D. Langewiesche and G. Schmidt (eds.), Föderative Nation, Deutschlandkonzepte von der Reformation bis zum Ersten Weltkrieg (Munich 2000).

2. See F. P. Kahlenberg, 'Preußen und die Annexionen des Jahres 1866. Nationalstaat und Selbstverwaltung während des Übergangsjahres in Kurhessen', Hessisches Jahrbuch fuir Landesgeschichte (1966), XVI, 165-214; D. S. White, The Splintered Party National Liberalism in Hessen and the Reich 1867-1918 (Cambridge and Lon 1976$) ; \mathrm{H}$. Ba Annexion und administrative Integration 1866-1868 (Hildesheim 1983); and Idem, 'Die hannoverschen Nationalliberalen 1859-1.885', Niedersächsisches Jahrbuch (1981), LIII, 65-85. 
3. P. Weichart, Raumbezogene Identität. Bausteine zu einer Theorie räumlich-sozialer Kognition und Identifikation (Stuttgart 1990).

4. M. Walker, Home Towns. Community, State, and General Estate, 1848-1871 (Ithaca 1971), 119-33.

5. See P. James, Nation Formation. Towards a Theory of Abstract Community (London 1996).

6. M. C. Smouts, 'The Region as the New Imagined Community', in Patrick Le Galés et al. (eds.), Regions in Europe (London 1998), 30-8.

7. W. Sewell, 'The French Revolution and the Emergence of the Nation Form', in M. Morrison and M. Zook (eds.), Revolutionary Currents: Transatlantic Ideology and Nationbuilding, 1688-1821 (Lanham 2004), 91-125.

8. J. Palmowski, Urban Liberalism in Imperial Germany, Frankfurt am Main, 1866-1914 (Oxford 1999). See also R. Roth, Stadt und Bürgertum in Frankfurt am Main. Ein besonderer Weg von der ständischen zur modernen Bürgergesellschaft (Munich 1996).

9. The inadequacy of the concept of the region as a tracer of tradition and anti-modernity is made clear by: C. Applegate, 'A Europe of regions. Reflections on the Historiography of Sub-national Places in Modern Times', American Historical Review (1999), CIV, 1157-82. The role of regionalism beyond the antagonism of modernity and anti-modernity is shown in the special issue on 'Municipalism, Regionalism, Nationalism: Hybrid Identity Formations and the Making of Modern Europe', edited by Maiken Umbach, European Review of History (2008), 3.

10. G. Lehmbruch, Parteienwettbewerb im Bundesstaat: Regelsysteme und Spannungslagen im politischen System der Bundesrepublik Deutschland, 3rd edn (Opladen 2000); and Idem, Der unitarische Bundesstaat in Deutschland: Pfadabhängigkeit und Wande (MPIfG Discussion Paper 02/2, Cologne 2002).

11. G. Moltmann, 'The American Constitutional Model and German Constitutional Politics', in R. C. Simons (ed.), The United States Constitution. The Firs 200 Years (Manchester 1989), 90-113; C. Ghisalberti, 'Il sistema politico americano e il costituzionalimsmo italiano del Risorgimento', Clio. Trimestrale di studi storici (1992), XXVIII, 340-52; and E. His, 'Amerikanische Einflüsse im schweizer Verfassungsrecht', in Festgabe der Basler Juristenfakultät und des Basler Juristênverein zum Schweizerischen Juristentag, September 1920 (Basel 1920), 81-110.

12. D. Groh and P. Brandt, 'Vaterlandslose Gesellen'. Sozialdemokratie und Nation 1860-1990 (Munich 1992), 31-43.

13. See S. Weichlein, 'Föderalismus und Bundesstaat zwischen dem Alten Reich und der Bundesrepublik', in I. Härtel (ed.), Handbuch Föderalismus. Föderalismus als demokratische Rechtsordnung und Rechtskultur in Deutschland, Europa und der Welt (Berlin 2012).

14. See S. Weichlein, Nation und Region. Integrationsprozesse im Bismarckreich, 2nd edn (Düsseldorf 2006).

15. See C. Lévi-Strauss, Mythos und Bedeutung (Frankfurt a. M. 1980), 40ff.

16. Weichlein, Nation und Region, $231 \mathrm{f}$

17. This argument was advanced by A. Milward, The European Rescue of the Nation State (London 1992).

18. For an excellent study on this phenomenon see Palmowski, Urban Liberalism.

19. Weichlein, Nation und Region, 261t

20. M. Hanisch, 'Für Fürst und Vaterland'. Legitimitätsstiftung in Bayern zwischen Revolution 1848 und deutscher Einheit (Munich 1991).
'।. W. Jütting and H. Weber (eds.), Die Heimat, 3rd edn (Leipzig 1876).

$\therefore$ See H. G. Haupt and C. Tacke, 'Die Kultur des Nationalen. Sozial- und kullurgeschichtliche Ansätze bei der Erforschung des europäischen Nationalismus im 19. und 20. Jahrhundert', in W. Hardtwig and $\mathrm{H}$. U. Wehler (eds.), Kulturgeschichte heute (Göttingen 1996), 255-83, 277f.; and D. Foitzik, 'Weihnachten', in II. Schulze and E. François (eds.), Deutsche Erinnerungsorte, Vol. 3 (Munich 2001), 154-68.

'3. (i. Kunz, Verortete Geschichte. Regionales Geschichtsbewußtsein in den deutschen historischen Vereinen des 19. Jahrhunderts (Göttingen 2000); and G. Clemens, Sanctus amor patriae. Eine vergleichende Studie zu deutschen und italienischen (ieschichtsvereinen im 19. Jahrhundert (Tübingen 2004), 328ff.

$\therefore$ I. T. van Rahden, 'Germans of the Jewish Stamm. Visions of Community between Nationalism and Particularism, 1850-1933', in M. Roseman et al. (eds.), German History from the Margins. 1800 to the Present (Bloomington 2006), 27-48.

$\therefore$. Weichlein, Nation und Region, 356-66.

‘. K. B. Murr, Das Mittelalter in der Moderne. Die öffentliche Erinnerung an Kaiser Ludwig den Bayern im Königreich Bayern (Munich 2008) and generally: M. Hanisch, 'Nationalisierung der Dynastien oder Monarchisierung der Nation? Zum Verhältnis von Monarchie, und Nation in Deutschland im 19. Jahrhundert', in A. M. Birke (ed.), Bürgertum, Adel und Monarchie. Wandel der Lebensformen im Zeitalter des bürgerlichen Nationalismus (Munich 1989), 7.1-91.

?\%. S. Mergen, Monarchiejubiläen im 19. Jahrhundert. Die Entdeckung des historischen Jubiläums für den monarchischen Kult in Sachsen und in Bayern (Leipzig 2005).

2. C. Applegate, A Nation of Provincials. The German Idea of Heimat (Berkeley 1990); and A. Confino, Nation as a Local Metaphor. Württemberg, Imperial Germany and National Memory, 1871-1918 (Chapel Hill 1997).

\%). Applegate, A Nation of Provincials, 13.

30. W. Hardtwig, 'Nationalismus - Regionalismus - Lokalismus. Aspekte der Erinnerungskultur im Spiegel von Publizistik und Denkmal', in E. Francois (ed.), Lieux de mémoire, Erinnerungsorte (Berlin 1996), 91-104; and E. Klueting (ed.), Antimodernismus und Reform: Zur Geschichte der deutschen Heimatbewegung (Darmstadt 1991)

31. Weichlein, Nation und Region, 105-190; J. O. Hesse, 'Heinrich von Stephan (1831-1897) - Unternehmer im Dienst der Staatsverwaltung', Archiv für deutsche postoeschichte (1998), 10-20; and Idem, Im Netz der Kommunikation. Fine Unternehmensgeschichte der Reichs-Post- und Telegraphenverwaltung 1876-1914 (Munich 2002)

32. Quote in G. Prüfer, Jetzt und überall und hier. Geschichte des Nachrichtenwesens (Berlin 1965), 264.

33. A. Seemann, 'Die "Postpaläste" Heinrich von Stephans. Zweckbauten für den Verkehr oder Architektur im Dienste des Reiches' (Unpublished Dissertation Kiel 1990).

34. F. Perrot, Die Anwendung des Penny-Porto-Systems auf den Eisenbahntarif (Rostock 1872); and J. Holzammer, Zur Geschichte der Briefportoreform in den Kulturstaaten von ihrem ersten Beginne 1837 bis zum Abschluß des Berner Weltpostvertrages (Tübingen 1879).

35. Weichlein, Nation und Region, 184-9.

36. G. Herrigel, Industrial Constructions. The Sources of German Industrial Power (Cambridge 1996). 
37. D. Ziblatt, Structuring the State. The Formation of Italy and Germany and the Puzzle of Federalism (Princeton 2006).

38. P. Manow, 'Germany: Cooperative Federalism and the Overgrazing of the Fiscal Commons', in F. G. Castles et al. (eds.), Federalism and the Welfare State (Cambridge 2005), 222-62, 227. See more generally P. Pierson, 'Fragmented Welfare States: Federal Institutions and the Development of Social Policy', Govemance (1995), VIII, 449-78.

39. P. Lewek, Arbeitslosigkeit und Arbeitslosenversicherung in der Weimarer Republik 1918-1927 (Stuttgart 1992). 


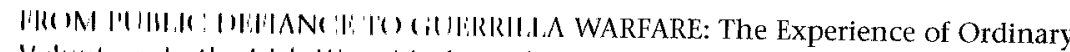

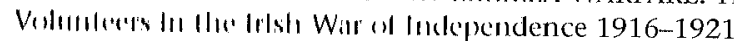

IIII: MI:M()IRS () J)HN M. RLGAN: A Catholic Officer in the RIC and RUC

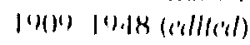

I'A'IRIC'K I'LARSE: 'The Making of a Revolutionary

IIII. IRISII REVOLUTION, 1913-1923 (edited)

IRLLI,AND IN THE 1930s: New Perspectives (edited)

IRISH HISTORY: A Research Yearbook (Number 1) (edited with Mary-Ann Lyons)

IRISH HISTORY: A Research Yearbook (Number 2) (edited with Mary-Ann Lyons and Deirdre MacMahon)

\section{Also by Eric Storm}

EL DESCUBRIMIENTO DEL GRECO: Nacionalismo y arte moderno (1860-1914) HET LAND VAN DON QUICHOT: De Spanjaarden en hun geschiedenis (edited with Raymond Fagel)

LA PERSPECTIVA DEL PROGRESO: Pensamiento político en la España del cambio de siglo (1860-1914)

THE CULTURE OF REGIONALISM: Art, Architecture and International Exhibitions in France, Germany and Spain, 1890-1939

\section{Region and State in} Nineteenth-Century Europe

\section{Nation-Building, Regional Identities and} Separatism

Edited by

Joost Augusteijn

Lecturer in European History, Leiden University, Leiden, the Netherlands

and

Eric Storm

Lecturer in Modern European History, Leiden University, Leiden, the Netherlands 


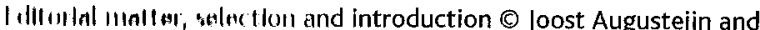
lik stomm dol?

All renunilulng chapters (c) their respective authors 2012

All rlghts reserved. No reproduction, copy or transmission of this publlcation may be made without written permission.

No portion of this publication may be reproduced, copied or transmitted save with written permission or in accordance with the provisions of the Copyright, Designs and Patents Act 1988, or under the terms of any licence permitting limited copying issued by the Copyright Licensing Agency,

Safron House, 6-10 Kirby Street, London EC1N 8TS.

Any person who does any unauthorized act in relation to this publication may be liable to criminal prosecution and civil claims for damages.

The authors have asserted their rights to be identified as the authors of this work in accordance with the Copyright, Designs and Patents Act 1988.

First published 2012 by

PALGRAVE MACMILLAN

Palgrave Macmillan in the UK is an imprint of Macmillan Publishers Limited, registered in England, company number 785998, of Houndmills, Basingstoke, Hampshire RG21 6XS.

Palgrave Macmillan in the US is a division of St Martin's Press ULC 175 Fifth Avenue, New York, NY 10010.

Palgrave Macmillan is the global academic imprint of the above companies and has companies and representatives throughout the world.

Palgrave ${ }^{\circledR}$ and Macmillan ${ }^{\circledR}$ are registered trademarks in the United States, the United Kingdom, Europe and other countries.

ISBN 978-0-230-31394-1

This book is printed on paper suitable for recycling and made from fully managed and sustained forest sources. Logging, pulping and manufacturing processes are expected to conform to the environmental regulations of the country of origin.

A catalogue record for this book is available from the British Library.

A catalog record for this book is available from the Library of Congress.

$\begin{array}{llllllllll}10 & 9 & 8 & 7 & 6 & 5 & 4 & 3 & 2 & 1\end{array}$

$\begin{array}{llllllllll}21 & 20 & 19 & 18 & 17 & 16 & 15 & 14 & 13 & 12\end{array}$

Printed and bound in Great Britain by

$\mathrm{CPI}$ Antony Rowe, Chippenham and Eastbourne

\section{Contents}

Acknowledgements

Notes on Contributors

1 Introduction: Region and State

Joost Augusteijn and Eric Storm

\section{Part I Transnational}

2 Historiographical Approaches to Sub-national Identities in Europe: A Reappraisal and Some Suggestions

Xosé-Manoel Núñez

3 The Birth of Regionalism and the Crisis of Reason: France, Germany and Spain

Eric Storm

\section{Part II Centralised Nation-States}

4 National Diversity, Regionalism and Decentralism in France Timothy Baycroft

5 Regionalism in Italy: A Critique Stefano Cavazza

\section{Part III Continental Empires}

6 Regionalism, Federalism and Nationalism in the German Empire

Siegfried Weichlein

7 How to Run a Multilingual Society: Statehood, Administration and Regional Dynamics in Austria-Hungary, 1867-1914 Peter Haslinger

Part IV Region, Nation, Empire

8 The Empire, the Nation and the Homelands: Nineteenth-Century Spain's National Idea Iosep $M$. Fradera 
1) 'A Mere Geographical Expression'? Scotland and Scottish Identity, c. 1890-1914

Andrew G. Newby

\section{Part V Competing Regional Movements}

10 Gaelic and Northumbrian: Separatism and Regionalism in the United Kingdom, 1890-1920 Robert Colls

11 Irish Nationalism and Unionism Between State, Region and Nation Joost Augusteijn

12 Nationalist Versus Regionalist? The Flemish and Walloon Movements in Belle Époque Belgium

Maarten Van Ginderachter

Part VI Language and Religion

13 The Consequences of Transport by Steam: Dutch Nationalism and Frisian Regionalism in the Nineteenth Century Goffe Jensma

14 Inadvertent Allies: Catholicism and Regionalism in a German-Polish Borderland James Bjork

Conclusion: Transnational Patterns Joost Augusteijn and Eric Storm 